\section{SAT0035 ANKYLOSING SPONDYLITIS, PSORIATIC ARTHRITIS AND REACTIVE ARTHRITIS SHOW INCREASED BONE RESORPTION AND DIFFER WITH REGARD TO BONE FORMATION}

1J Grisar, ${ }^{1} \mathrm{M}$ Aringer, ${ }^{1} \mathrm{~K}$ Redlich, ${ }^{2} \mathrm{PM}$ Bernecker, ${ }^{3} \mathrm{~W}$ Wolozcszuk, ${ }^{1} \mathrm{JS}$ Smolen, ${ }^{4} \mathrm{P}$ Pietschmann. ${ }^{1}$ Department of Internal Medicine III; ${ }^{2}$ Department of Internal Medicine III; ${ }^{3}$ Ludwig Boltzmann Institute of Experimental Endocrinology, Division of Rheumatology; ${ }^{4}$ Department of Pathophysiology, Vienna, Austria

\subsection{6/annrheumdis-2001.387}

Background It is well established that rheumatoid arthritis is associated with severe alterations of bone metabolism. In seronegative spondylarthropathies (SSPs), however, data on bone turnover are scarce and conflicting.

Objectives

Methods We studied biochemical markers of bone resorption (urinary deoxy-pyridinoline (D-Pyr) and cross-linked telopeptide of collagen-1 (ICTP)), bone formation markers (osteocalcin (OC) and bone specific isoenzyme of alkaline phosphatase (BAP)) as well as serum levels of osteoprotegerin (OPG, a glycoprotein which prevents the differentiation and activation of osteoclasts) in 30 patients with ankylosing spondylitis (AS), 23 patients with psoriatic arthritis (PsoA), 10 patients with reactive arthritis (ReA) and sex- and age matched healthy controls (HC).

Results Markers of bone resorption were significantly increased in AS, PsoA and ReA patients (Table 1). In contrast, bone formation markers were found to be heterogeneous: OC was increased in AS, but not in PsoA or ReA and the levels of BAP were elevated only in patients suffering from PsoA (Table 1). Serum levels of OPG were significantly increased in the AS and PsoAgroup (Table 1). Furthermore, dual energy x-ray absorptiometry (DXA) measurements of the lumbar spine and the femoral neck, performed in a subgroup of patients, showed clearly decreased T-scores (lumbar spine $-0.99 \pm 1.33$, femoral neck $-1.95 \pm$ 1.33 ) in patients suffering from AS. In PsoA bone mineral density was within the normal range. ${ }^{*}=p<0.05$. ${ }^{* *}=p<$ 0.001 .

\begin{tabular}{|c|c|c|c|c|c|c|}
\hline & AS & $\mathrm{HC}$ & PsoA & $\mathrm{HC}$ & $\operatorname{Re} A$ & HC \\
\hline OPG & $\begin{array}{l}44.3 \pm \\
19.7 \text { * }\end{array}$ & $\begin{array}{l}32.7 \pm \\
7.6\end{array}$ & $\begin{array}{l}47.4 \pm \\
22.6 \text { * }\end{array}$ & $\begin{array}{l}35.7 \pm \\
8.3\end{array}$ & $\begin{array}{l}45.3 \pm \\
23.2\end{array}$ & $\begin{array}{l}37.3 \pm \\
11.1\end{array}$ \\
\hline BAP & $\begin{array}{l}11.0 \pm \\
4.5\end{array}$ & $\begin{array}{l}10.4 \pm \\
3.6\end{array}$ & $\begin{array}{l}12.5 \pm \\
4.6 \text { * }\end{array}$ & $\begin{array}{l}9.8 \pm \\
3.1\end{array}$ & $9.1 \pm 3.3$ & $\begin{array}{l}9.1 \pm \\
2.5\end{array}$ \\
\hline$O C$ & $\begin{array}{l}22.0 \pm \\
6.8^{*}\end{array}$ & $\begin{array}{l}18.2 \pm \\
5.7\end{array}$ & $\begin{array}{l}20.7 \pm \\
7.3\end{array}$ & $\begin{array}{l}17.8 \pm \\
5.7\end{array}$ & $\begin{array}{l}16.8 \pm \\
3.4\end{array}$ & $\begin{array}{l}15.3 \pm \\
5.0\end{array}$ \\
\hline ICTP & $\begin{array}{l}4.7 \pm 1.6 \\
* *\end{array}$ & $\begin{array}{l}3.2 \pm \\
0.7\end{array}$ & $\begin{array}{l}4.8 \pm 1.8 \\
* *\end{array}$ & $\begin{array}{l}3.1 \pm \\
0.6\end{array}$ & $\begin{array}{l}4.8 \pm 1.4 \\
* *\end{array}$ & $\begin{array}{l}3.2 \pm \\
0.8\end{array}$ \\
\hline $\begin{array}{l}\text { D-Pyr } \mathrm{nmol} / \mathrm{mmol} \\
\text { creatinine }\end{array}$ & $\begin{array}{l}6.4 \pm 2.7 \\
* *\end{array}$ & $\begin{array}{l}4.5 \pm \\
1.4\end{array}$ & $\begin{array}{l}6.2 \pm 2.2 \\
* *\end{array}$ & $\begin{array}{l}4.2 \pm \\
1.5\end{array}$ & $\begin{array}{l}8.0 \pm 3.4 \\
*\end{array}$ & $\begin{array}{l}4.5 \pm \\
1.1\end{array}$ \\
\hline
\end{tabular}

Conclusion Our results suggest significant alterations of bone metabolism in patients with SSPs. It is tempting to speculate that the increased OPG levels in AS and PsoA may represent a compensatory mechanism following enhanced bone resorption.

\section{SAT0036 SUCCESSFUL TREATMENT OF SAPHO SYNDROME WITH INFLIXIMAB: REPORT OF TWO CASES}

${ }^{1}$ I Olivieri, 'A Padula, ${ }^{1} \mathrm{G}$ Ciancio, ${ }^{2} \mathrm{C}$ Salvarani, ${ }^{3} \mathrm{~N}$ Niccoli, ${ }^{3} \mathrm{~F}$ Cantini. ${ }^{1}$ Rheumatology Department of Lucania, San Carlo Hospital, Potenza, Italy; ${ }^{2}$ Rheumatic Disease Unit, Arcispedale Santa Maria Nuova, Reggio Emilia, Italy; ${ }^{3}$ Rheumatic Disease Unit, Prato Hospital, Prato, Italy

\subsection{6/annrheumdis-2001.388}

Background SAPHO syndrome (synovitis, acne, pustolosis, hyperostosis, osteitis) syndrome shares manifestations and clinical association with the spondyloarthropathy (SpA) complex.

Nonsteroidal anti-inflammatory drugs (NSAIDs) are the first choice but have limited effcacy. Second-line drugs have been tried with mixed results. Positive effects with pamidronate, which partly works by blocking tumour necrosis factor alpha (TNFalpha), have recently been reported. Infliximab, a chimeric anti-TNFalpha monoclonal IgG1 antibody, has recently been proved to be effective in ankylosing spondylitis (1) and psoriatic arthritis. $^{1-3}$

Objectives To evaluate the effect of infliximab in patients with SAPHO syndrome resistant to NSAIDs and second-line drugs.

Methods Two patients meeting criteria for SAPHO syndrome and with chest wall pain limiting normal activity despite adequate treatment with NSAIDs and who had failed second-line therapy received three intravenous infusions of infliximab $(5 \mathrm{mg} /$ $\mathrm{Kg}$ ) at weeks 0,2 , and 6 . One of the two patients had skin manifestations consisting in severe acne at baseline. Patients were evaluated at baseline and on days 3, 7, 14 and from then every two weeks for the following variables: anterior chest wall pain, swelling and tenderness, erythrocyte sedimentation rate (ESR) and C-reactive protein (CRP).

Results The two patients had a complete response to therapy 3 days after the first infusion of infliximab and discontinued NSAID therapy. Chest wall swelling and tenderness remitted and CRP became normal. Sever acne dramatically improved in one week after the first infusion. Patients remained symptom-free after the third infusion up to 2 months' follow-up. Infliximab treatment was well tolerated, with no adverse event.

Conclusion Infliximab seems to be an effective drug in SAPHO syndrome. A larger, controlled, double-blind study is required.

\section{REFERENCES}

1 Brandt J, et al. Ann Rheum Dis. 2000;43:1346-52

2 Van der Bosch F, et al. Ann Rheum Dis. 2000;59:428-33

3 Antoni C, et al. J Rheumatol. 2000;27(Suppl 59):24

\section{SAT0037 MYOCARDIAL INVOLVEMENT IN PATIENTS WITH ANKYLOSING SPONDYLITIS}

${ }^{1} \mathrm{~N}$ Tas, ${ }^{1} \mathrm{~S}$ Alpaslan, ${ }^{2} \mathrm{M}$ Alpaslan. ${ }^{1}$ Physical Medicine and Rehabilitation, Gazi University, Faculty of Medicine, Ankara, Turkey; ${ }^{2}$ Cardiology, Afyon Kocatepe University, Afyon, Turkey

\subsection{6/annrheumdis-2001.389}

Background Ankylosing spondylitis (AS) is a chronic systemic disease that may involve aorta and the heart. Aortitis, aortic valve insufficiency, pericarditis, cardiac conduction abnormalities and cardiomegaly have been reported in patients with AS. It is not clear whether cardiac muscle changes are due to primary involvement of the cardiac muscle or secondary to aortic and valvular involvement in this disease.

Objectives To evaluate the presence of ongoing myocyte necrosis in patients with active AS. 